\title{
Estrogen-induced changes in the hepatic metabolism of plasma lipoproteins in the pre-ruminant calf
}

\author{
$S$ Auboiron ${ }^{1}$, D Durand ${ }^{1}, J$ Lefaivre ${ }^{2}$, \\ D Bauchart ${ }^{1}, \mathrm{MJ}$ Chapman $^{3}$ \\ 'INRA Theix, Unité de Recherche des Métabolismes Energétique et Lipidique; \\ ${ }^{2}$ Unité Dynamique de Digestion, 63122 Saint-Genès-Champanelle; \\ ${ }^{3}$.NSERM U321, Unité de Recherche sur les Lipoprotéines et l'Athérogénèse, \\ Hôpital de la Pitié, 75651 Paris Cedex, France
}

The hepatic synthesis and secretion of lipoproteins such as VLDL and HDL is particularly important in lipoprotein homeostasis in bovine species (Bauchart et al, 1989). On the one hand, VLDL-mediated hepatic triglyceride export is low and can be limiting during lipomobilization, while on the other hand, HDL, which accounts for more than $75 \%$ of total plasma lipoproteins, plays a major role in reverse cholesterol transport in these species. In order to stimulate the hepatic production of lipoproteins, estrogen was administered to three 3-week-old male Friesian calves (55 $\pm 3 \mathrm{~kg}$ body weight) equipped with catheters and electromagnetic flow probes for estimation of hepatic lipoprotein fluxes. Animals were fed a conventional milk replacer in which lipid and carbohydrate content was reduced to $30 \%$ in order to induce lipomobilization. $17 \beta$-Estradiol (E) was then administered by infusion through the portal route $(20 \mu \mathrm{g}$ per $\mathrm{kg} \mathrm{BW})$ for $1 \mathrm{~h}$ after the morning meal and subsequently by intramuscular injection $(200 \mu \mathrm{g} / \mathrm{d}$ per $\mathrm{kg} \mathrm{BW}$ ) over the following $4 \mathrm{~d}$. Blood samples were collected $7 \mathrm{~h}$ after the morning meal. Total plasma lipoproteins (d $<1.180 \mathrm{~g} / \mathrm{ml}$ ) were separated by density-gradient ultracentrifugation into 22 subfractions and their respective chemical composition was determined by enzymatic and immunological methods.
Estrogen treatment did not significantly modify the physicochemical properties and density distribution of bovine plasma lipoproteins. In spite of restrictive energy supply, low levels of hepatic VLDL production were observed under control conditions $(0.09 \mathrm{mg} / \mathrm{min}$ per $\mathrm{kg}$ BW). Hepatic VLDL production was stimulated by estrogen perfusion (EP) $(0.32 \mathrm{mg} / \mathrm{min}$ per $\mathrm{kg} \mathrm{BW})$ but strongly reduced by the long-term treatment of estrogen administered by intramuscular injection (El) $(-0.62 \mathrm{mg} / \mathrm{min}$ per $\mathrm{kg}$ $\mathrm{BW})$; these findings emphasize the importance of the route of administration and the hormonal dose under our dietary conditions. Estrogen treatment stimulated hepatic production of light HDL $(1.060-1.091 \mathrm{~g} / \mathrm{ml})(-2.71 \mathrm{vs}$ 1.17 and $2.16 \mathrm{mg} / \mathrm{min}$ per $\mathrm{kg} \mathrm{BW}$ in control, EP and El treatment respectively) and hepatic uptake of heavy HDL $(1.091-1.180 \mathrm{~g} / \mathrm{ml})(2.35 \mathrm{vs}-0.52$ and $0.13 \mathrm{mg} / \mathrm{min}$ per $\mathrm{kg} \mathrm{BW}$ ). Modification in the hepatic metabolism of HDL by estrogen may involve a decrease in hepatic lipase activity (Hazzard et al, 1984) and cholesterol esterification by LCAT.

Bauchart D, Durand D, Laplaud PM, Forgez P, Goulinet S, Chapman MJ (1989) J Lipid Res 30, 1499-1513

Hazzard WR, Haffner SM, Kushwaha RS, Applebaum-Bowden D, Foster DM (1984) Metabolism 33, 779-784 